\title{
A Pragmatics of Ritual: The Yoshida Goma at the Interface of Shintō and Shingon
}

\author{
Richard K. Payne
}

check for

updates

Citation: Payne, Richard K. 2021. A Pragmatics of Ritual: The Yoshida Goma at the Interface of Shintō and Shingon. Religions 12: 884. https://doi.org/10.3390/rel12100884

Academic Editor: Jeffrey L. Richey

Received: 28 August 2021

Accepted: 12 October 2021

Published: 15 October 202

Publisher's Note: MDPI stays neutral with regard to jurisdictional claims in published maps and institutional affiliations.

Copyright: (C) 2021 by the author. Licensee MDPI, Basel, Switzerland. This article is an open access article distributed under the terms and conditions of the Creative Commons Attribution (CC BY) license (https:/ / creativecommons.org/licenses/by/ $4.0 /)$.
Institute of Buddhist Studies, Graduate Theological Union, Berkeley, CA 94709, USA; rkpayne@shin-ibs.edu

\begin{abstract}
Drawing on practices and teachings from Daoism, neo-Confucianism, and tantric Buddhism, Yoshida Kanetomo (1435-1511) created the system of Yuiitsu Shintō, also known eponymously as Yoshida Shintō, all the while making claims for Shintō as the world's original religion. Important for the establishment of Yoshida Shintō was the creation of a program of rituals. This essay examines one of the three rituals created for the Yoshida ritual program, the Yoshida Shinto goma ritual, which hybridizes tantric Buddhist ritual organization and Daoist symbolism. A pragmatics of ritual is developed as a means of identifying the factors that Yoshida felt were salient in presenting the goma as a Yoshida Shintō ritual.
\end{abstract}

Keywords: Yoshida Shintō; goma; Shingon; pragmatics; ritual; tantric Buddhism

\section{Introduction}

Yoshida Shintō (吉田神道), also known as Yuiitsu Shintō (唯一神道, the “one and only Shintō"), was established by Yoshida Kanetomo (吉田兼俱, 1434-1511), an heir of a branch of the Urabe family line, an aristocratic family dating from the earliest period of Japanese history (Breen and Teeuwen 2010, pp. 47-52). The ritual praxis of Yoshida Shintō was structured around three rituals, one of which is a fire ritual, goma (護摩, Skt. homa). This goma exemplifies the creation of a new ritual, hybridizing tantric Buddhist elements from Indic and Daoist sources, and neo-Confucian elements from Sinitic ones in the context of medieval Japanese Shintō.

For the field of religious studies, this inquiry focuses on the issue of definitional strategies, developing a pragmatics of ritual that looks at use and context as an alternative to earlier strategies. Any definitional strategy is of course heuristic, and part of the heuristic value of the use and context approach is that it avoids constraining our understanding of ritual praxes by conceptions of interactions or influences between monolithic and mutually exclusive traditions (Grapard 2006-2007, pp. 2-3).

Conceiving traditions as mutually exclusive monoliths often results in framing otherwise organic interactions as syncretism, that is, invoking the rhetoric of impurity in contrast with the putative purity of the source traditions. Impurity and its cognate unorthodoxy are, however, value judgements largely based on institutionalized power structures. As such, they impede understanding the historical realities of how traditions grow and change over time, while hybridity carries fewer negative connotations.

This essay is organized into four sections. The first introduces the reader to the goma and provides a brief history of its transmission from early medieval India to fifteenth century Japan, and to the origins of the Yoshida Shintō tradition. One way of thinking about the relation between Yoshida and Shingon gomas is to frame the issue as a definitional one. The value of a pragmatic approach is demonstrated in the second section, which briefly examines the most common definitional strategies that have been employed in the past, and the problems attendant on those. In the third section, an approach based on "context and use" is proposed. This adapts the idea of pragmatics from the study of language to the study of ritual, while avoiding the pitfalls of more formally definitional approaches. McDermott (1975) uses the terminology of "indices" for specific pragmatically significant 
markers, a usage we follow here. This allows us then in the fourth section to construct a principled examination of salient pragmatic features that distinguish the Yoshida Shintō goma from the Shingon goma.

A terminological note: For the purposes of this essay, it is not useful to attempt to distinguish usages of "tantric Buddhism" and "esoteric Buddhism", which are both used here as synonymous glosses for the Japanese term mikkyō (密教). We note, however, that authors working in other contexts have found it important to make such distinctions (see Orzech et al. 2011, pp. 4-18).

\section{Across the Longue Durée: Goma from India to Japan}

The Indic homa ritual, which is the genealogical precursor to the Japanese Buddhist goma, is structured by the metaphor of feasting an honored guest practiced in much of Indic ritual culture. This host-guest metaphor dates from the Vedic origins of tantric ritual. The metaphor provides an organizing program for these votive rituals-the practitioner is the host who invites the deity as a guest into a ritual enclosure. The ritual enclosure is an altar, which in the case of tantric Buddhism is also a mandala. At the center of the altar is a hearth in which a fire is built. The guest is welcomed with offerings appropriate to the deity's status as an honored guest, such as water for washing, both burnt incense for a pleasant odor and incense paste for the deity's body, as well as festive lights and music. Then the ritual proceeds to offerings of food and drink made into the fire, which is identified with the purifying power of Agni (J. Katen, 火天). The homa continues across the entire historico-cultural range of tantric rituals, including Hindu and Buddhist, as well as related Jain versions, into the present day.

The homa ritual originates from Vedic and Iranian rites that themselves date from about two millennia before Śākyamuni, and then in medieval India it is transformed into a tantric rite. The adaptation into tantric Buddhism was accomplished in part by fitting it into the latter's ideological understandings of the ground, path, and goal, a framework used to identify an integrated understanding of the human condition (ground), the course of practice (path), and the character of awakening (goal, also fruition). This adaptation also involved changing or replacing such ritual elements as mantra and deities. This tantric Buddhist rite was then transmitted from India to Tang China, where it formed an important part of the ritual corpus of tantric Buddhism, the "mantra school" (Zhenyan 眞言, J. Shingon, and also related to the "Yoga Teaching," yuqiejiao 瑜伽教) (Orzech 2006, p. 47). That version was transmitted on to Japan, while there was a separate and later transmission of tantric ritual praxes from India to Tibet. Kūkai (774-835, 空海), considered the founder of the Shingon tradition, was part of a government envoy from the Heian court to the Tang court in 804 . When Kükai returned from China, he was authorized by the emperor to establish the Shingon tradition, and one of the rituals that were introduced by Kükai at this time is the homa (goma 護摩).

Over the next centuries, Japan's Buddhist culture was increasingly influenced by tantric, that is, mikkyō praxis, mostly through the Shingon and Tendai sects. Kuroda Toshio (1926-1993) has argued that this integration of tantric Buddhism with other forms was so pervasive as to constitute the orthodoxy of medieval Japan. Kuroda labeled this the esotericexoteric system (kenmitsu taisei 顯密体制), and the pervasion of Japanese Buddhism by tantric praxis has been referred to as the "mikkyo-ization" of Japanese religion (Kuroda 1996). Shingon ritual praxis, including the goma, was a key part of this transformation, and contributed to further ritual developments in other traditions. One is the Shugendō tradition of mountain asceticism, which includes both a protective goma (sokusaihō 息災 法; Skt. śāntika) performed inside temples, and a Shugendō saitō goma (修験道齋燈護摩), which is performed out of doors, either independently or as part of larger ceremonials (Miyake 1989, p. 106; and Miyake 2001, pp. 89-91; see also Bouchy 2009; and Sekimori 2011). Today the Shinnyo-en tradition also performs saito goma on at least an annual basis (https:/ / www.shinnyoen.org/news/shinnyo-annual-saito-homa.html (accessed on 
11 August 2021)). In addition to these, there are also Shintō forms, such as the Yoshida Shintō goma discussed here.

Seven centuries after the introduction of tantric Buddhism from China, Yoshida Kanetomo worked to adapt the Shingon tantric goma as one of three rituals constituting a new systematization of Shintō praxis. In other words, the praxis of tantric Buddhism was now being adapted to serve the needs of a newly envisioned Shintō tradition.

\subsection{Yoshida Shintō: Historical Background}

Yoshida Shintō is one of the religious traditions formulated in the medieval period that asserted a self-identity as Shintō per se. The thirteenth century is considered to be the "point that one encounters the beginnings of a self-conscious discourse" that can be identified as Shintō (Bowring 2005, p. 352). These movements constituted a kind of religious nationalism, working to create a distinctly Japanese form by contrasting themselves with Buddhism as a foreign cult. Contrary to Buddhism, which located authority first in the distant and semimythical India, and then in the more proximate China, these new religious movements located authority within Japan itself (Bowring 2005, 345 ff.). Thus, the context within which Yoshida Kanetomo was establishing the new tradition of Yoshida Shintō was not only a religious culture saturated with tantric elements, but also included other newly developing traditions that self-identified as Shintō. Earlier movements included the Watarai Shintō of the Ise Outer Shrine (see Teeuwen 2002), and Miwa-ryu (Andreeva 2010; and Andreeva 2017; cf. Bowring 2005, pp. 349, 50).

Specialized ritual functions were assigned to the ruler's allies from as early as the fifth century, during the reign of the Yamato ruler Yūryaku. Among these, the Urabe were diviners "who used tortoise shells and deer scapulae to predict the future, heating these objects over fire until cracks appeared and then uttering prophecies based on the pattern of cracks" (Hardacre 2017, p. 25). These forms of divination practices, plastromancy and scapulimancy, are known on the continent from as early as the Shang dynasty and appear to have been imported to Japan by immigrants from the continent (Nickel 2011). ${ }^{1}$

In 859, the Urabe clan had been given the responsibility of supervising a shrine in the Yoshida district of Kyoto (Hardacre 2017, p. 211; Maeda 2003, pp. 26-27). ${ }^{2}$ Moreover, in 1375 , Urabe Kanehiro moved his residence to the area near the shrine and took Yoshida as his surname. "This caused the Urabe line to be divided into two branches, Hirano and Yoshida, each branch taking its name from the shrine that it managed" (Maeda 2003, p. 30). Before the advent of Buddhism, the Urabe had been one of the two houses of ritual specialists to the court. Thus, we may reasonably conclude that Kanetomo had personal motivations for establishing a distinctly Shintō form, a project at which he was notably successful. Indeed, having gained authority to provide "certificates of rank for local deities" independently from the ritual practices of the court, Yoshida Shintō became the predominant form of Shintō during the late medieval period, expanding out into a network of relations built on these connections to local shrines (Maeda 2003, p. 49). "On the basis of the groundwork Kanetomo laid, the Yoshida House exercised preeminent influence over the shrine priesthood, beginning in the late fifteenth century and enduring until the late nineteenth century, waning only with the ascendency of National Learning (Kokugaku)" (Hardacre 2017, p. 211).

\subsection{Rituals of Yoshida Shinto}

That Kanetomo gave the name "Yuiitsu Shintō", that is, the "one and only Shinto", to his new system suggests that he was motivated by both a much grander vision and a greater ambition than previous self-identified Shintō developments. He worked to not simply assert the importance of the Yoshida shrine as one among many, but as the only institutional form of Shintō that would bring all local temples into a single, unified system across the entire domain (Maeda 2002, p. 329). To do this, he constructed a tradition out of existing Shintō elements, together with elements from China, largely Daoist but 
also neo-Confucian, as well as Esoteric Buddhist practices, imagery, and ideas. Hardacre explains that

While Kanetomo's appropriations are undeniable, Kanetomo's Buddhist and Daoist references would have been fully apparent to his contemporaries as well. It is not that he borrowed elements covertly or hoped that no one would notice. Instead, he asserted that Shinto was prior to and thoroughly pervades all other teachings. He hoped to show through ritual that Shinto is ultimately the basis for Buddhism and Daoism, to show that they derive from Shinto, rather than the reverse (Hardacre 2017, p. 225).

Kanetomo's assertion that Shintō is primordial is evidenced by his inversion of the relation between buddhas and bodhisattvas on one side and kami on the other. Prior to this, the relation was structured by the theory of "original sources, earthly traces" (honji suijaku, 本地垂迹). According to this theory, buddhas and bodhisattvas are the original sources (honji), and the kami are their earthly traces (suijaku), which "implies that the honji is superior to the suijaku, like a body is different from the footprints it leaves in the snow" (Grapard 2006-2007, p. 10). In keeping with his claims regarding the primordial nature of Shintō, Kanetomo's ideology inverted this relation, asserting that the kami were the original sources and the buddhas and bodhisattvas were merely earthly traces (Grapard 2006-2007, p. 6).

Kanetomo's key doctrinal text, the Yuiitsu Shintō Myōbo Yōsh $\bar{u}$, was written around 1485. In this, Kanetomo distinguished two strains of Shintō doctrine, exoteric ("open teachings") and esoteric ("secret teachings"), each based in a set of three texts (Scheid 2006, p. 298). Specifically, "exoteric Shinto is based on three books of mythology and history, and esoteric Shinto is based on three scriptures revealed by the Lord of the Polar Star to Ame-no-koyane-no-mikoto, and, hence, to the Urabe lineage" (Grapard 1992, p. 50). In doing so, Kanetomo employed the rhetoric of secrecy current in medieval Japan in order to claim that the Yoshida teachings and practices were the esoteric counterpart to the Kojiki and Nihon Shoki, and that they had been closely held secrets since those ancient times (see Scheid and Teeuwen 2006).

The Yoshida shrine was destroyed in 1468, and Kanetomo took advantage of the opportunity to transform it from a tutelary shrine for the Fujiwara clan into an expression of his ideology, promoting it as the "supreme cult site in Japan" (Maeda 2003, p. 42). Included in this comprehensive vision was the set of three rituals, which were "purportedly so secret that they had never been disclosed since the divine age, but in fact mostly creations by Yoshida Kanetomo" (Scheid 2006, p. 301). Now used in a Shintō context, the three drew on Esoteric Buddhist and Daoist resources (Grapard 1992, p. 48).

Kanetomo's hybridizing of elements from diverse sources raises a theoretical issue regarding just what defines a category such as Shintō? From one perspective, selfidentification may be taken as definitive, in other words, the Yoshida tradition is Shintō because Kanetomo said it is, and others accepted that designation. A different perspective, however, may ask, how it is that Kanetomo's claim was convincing? A similar problem has existed in the study of tantra, and reflections on the definitional strategies employed for that tradition are relevant to our inquiry here.

\section{Seeing Tantra: Definitional Strategies}

The scholarly study of tantra has been impeded by a variety of factors. Most prominent among these was the sense of moral, religious, and cultural superiority on the part of European and American scholars in the nineteenth century. An Orientalist disdain (see Payne 2021, pp. 302-6) for the living traditions and a privileging of doctrine and doctrinal texts were both consequences of these Victorian attitudes. More recently, however, tantric Buddhism has come to be recognized as a valid area of scholarly inquiry. This is not the venue to review either this history or the cultural presumptions that have complicated the study of tantra, both of which have been explored by others already (see Orzech 1989; and Urban 2003, p. 19). Instead, here we wish to highlight an epistemological issue, that 
is, the definitional strategies that have been employed to identify tantra. After briefly summarizing those strategies and their shortcomings, we will propose an alternative that can assist us to understand the hybridity of Yoshida Shintō ritual praxes.

The definitional strategies that have been used over the last half century can be grouped, if somewhat roughly, into three kinds: A single defining characteristic, a list of characteristics, and family resemblances, which is also known more technically as a polythetic definition. Although there are other possible definitional strategies, such as stipulative and genus/species, those do not seem to have enjoyed much currency in the scholarly study of tantra. The first assumes that some single essential characteristic exists in each instance of tantra, and conversely, its absence from some instance means that it is not tantra. That characteristic is, in other words. both necessary and sufficient. A prominent example is the idea of ritual identification, that is, the practitioner "knows that the three essential agents of the rite- the chief divinity, the fire, and himself, the officiant-form but a single entity, and he unites them in his meditation" (Strickmann 1983, p. 439). Given, however, that there are tantric traditions that do not give ritual identification a prominent role in their ritual praxis, this cannot serve as a defining characteristic (Payne 2011b). Indeed, our increasing familiarity with the wide range of tantra indicates that no single characteristic, no matter how ideologically central to some particular form of tantra, can serve as the defining characteristic of tantra understood inclusively.

The second approach is that of listing typical characteristics. This assumes that while there may be no one single defining characteristic, a list of several can be formulated. In a strong version, this would mean that all of the characteristics on the list are necessary, and that no particular characteristic is sufficient. There have been a number of such attempts over the past decades, from brief lists of three or four items (Schopen 1982, p. 105) to more extended lists of a dozen or more (Hodge 2003, pp. 4-5). The varied membership of such lists indicates that they are idiosyncratic, pointing to the concerns of the scholar compiling the list, rather than to a set of essential characteristics.

Third, like the list approach, the family resemblances approach assumes that different instances of tantra share some set of characteristics-but unlike the list approach, assumes that not all characteristics are shared. In contrast to the strong list approach in which all of the members of the list are considered necessary, this might be called a sort of "soft" list approach. At the same time, none of the characteristics are considered essential, unlike the emphasis on a single defining characteristic. In this soft version, in other words, a number of the characteristics are necessary, while no single one is sufficient. In application, however, it usually seems that little attention is given to identifying exactly which characteristics are shared as family resemblances, nor to how many are required, nor to how they relate to one another-with "family resemblances" appearing to be all too often invoked as a way of presenting the appearance of epistemological sophistication, but without actually establishing the range of characteristics and the significance of their relations to one another.

In contrast, one strain within the research on tantra has long emphasized tantra's dynamic character. Robert L. Brown talks about tantra as a "process rather than as a static structure of characteristics. Emphasis on process points out that Tantrism is predominantly action, either physical or mental, with less stress on belief, doctrine, or theology" (Brown 2002 , p. 2). Beyond this processual conception, however, tantra is a coherent pattern that does not depend upon specific individual elements. That pattern-based ontic status means that there is an additional difficulty with all three of the definitional strategies described above-all are category mistakes. They are looking to identify tantra by its elements, rather than by its pattern. One of the locations in which the patterns of a tradition are made evident is in its cultic praxes.

All definitional strategies-including context and use, discussed below-are only meaningful as they play a part in research projects. Consequently, their value may be judged heuristically, that is, by a sharply constrained evaluation of how well they contribute to generating new knowledge through the research project of which they are a part. The argument being made here is not that context and use is a superior definitional strategy 
for all research projects- that depends on the questions being asked, and whether the definition serves to answer those questions. Rather, in the study of tantra-and religion more generally-context and use help to avoid two more general sets of methodological problems. First, those that follow from dysfunctionally reified conceptions of traditions, such as value-laden judgements regarding purity, orthodoxy, and syncretism, and second, from the category mistake of thinking that tantra is identified by any of the elements in its pattern. Patterns of human behavior are maintained over time by use in a context. Here we propose that "context and use" provide an alternative definitional strategy, one that does not create pseudo-problems based on thinking in terms of reified, monolithic traditions, nor the category mistakes of looking for parts of the pattern that can be treated as if definitive.

\section{Context and Use: A Pragmatics of Ritual}

The Shingon goma and the Yoshida Shintō goma appear to be very similar. What then distinguishes a tantric Buddhist goma from a Yoshida Shintō goma? A methodological strategy for the study of ritual that has proven beneficial in the past has been to borrow concepts, categories, and concerns from the field of linguistics. Compared with ritual studies, linguistics is a very well-developed field, and therefore can provide sophisticated ways of thinking about ritual. This requires, however, that the analogy between language and ritual be clear. For the purpose of developing a pragmatics of ritual, the analogy is:

1. Language and ritual are alike as having significance in social systems.

2. The significance of language is conditioned by context and use (pragmatics).

Therefore, the significance of ritual is conditioned by context and use.

This analogy can benefit from some further explication. First, the analogy is limited because language and ritual are unlike one another. In general, language is communicative speech and ritual is performative action. Second, the concept of "significance" is used as a more expansive concept than "meaning" and as more relevant to discussions of pragmatics. Third, the analogy between language and ritual being employed here differs from other treatments that claim an analogy between the two, such as the related characterizations as didactic, formative, or communicative. Rituals are considered didactic when seen as instructing the participants or audience in particular beliefs or values. They are characterized as formative when specific ideas about self and the world are conveyed authoritatively. Moreover, in some cases, ritual is portrayed as a form of communication.

A.C.S. McDermott, almost a half century ago now, employed the idea of linguistic pragmatics in an essay on mantra recitation, which is relevant here because it examines the activity of reciting mantra, rather than the more commonly encountered explicitly linguistic issues, such as whether or not mantra are meaningful, and if so in what way. Because of its "clarity and breadth" (McDermott 1975, p. 273), McDermott provisionally employs a characterization of pragmatics given by R.C. Stalnaker. We can make explicit what McDermott has implied by rephrasing that characterization in terms of the study of ritual:

Ritual pragmatics is the study of ritual acts and the contexts in which they are performed. There are two major types of problems to be solved within ritual pragmatics: First to define interesting types of ritual acts and ritual forms; second, to characterize the features of the ritual context that help determine what significance can be attributed to a given ritual performance.

McDermott chooses as a paradigmatic instance a sequence of two recitations of mantra from the Four Maṇdala ritual for Tārā discussed in detail by Stephen Beyer. The two recitations are delineated in terms of their illocutionary force as contemplative and evocative (terminology from Beyer 1973, p. 67; see McDermott 1975, n. 19). McDermott details an abstract set of pragmatic conditions for the successful performance of the recitation. This treatment of mantra recitation retains preconceptions that follow from thinking of mantra as communicative language, including the implication that a "successful performance" of mantra meets the same conditions as a successful linguistic communication of information 
from one party to another, with most linguistic pragmatics being based on a model of dyadic communication. Elsewhere, I have critiqued that preconception of mantra (Payne 2018), and in the same way here am attempting to suggest a pragmatics of ritual that does not entail preconceptions that follow from a focus on what constitutes a successful activity. Focusing on the "success" of ritual activity would replicate the longstanding preconception that ritual is instrumental. This instrumental attitude is exemplified by the question as to whether rain-making rituals "actually" make rain. McDermott's identification of the pragmatic conditions, or "indices", in terms of those necessary for a successful recitation of mantra, draws particularly on Richard Montague's ideas regarding the pragmatic conditions required for successful linguistic communication (see Janssen and Zimmermann 2021 , § 3.4). Given the problematic character of thinking about rituals as successful or not, we are suggesting instead that a pragmatics of ritual be oriented toward the context and use of ritual. In other words, because notions of what constitutes the success of a ritual are so heavily laden with value judgements and theological preconceptions, understandings of the study of ritual that depend on evaluating whether or not a ritual is instrumentally successful should be abandoned as epistemologically flawed.

In her analysis, McDermott groups together "aptness of time, place, concomitant gestures (mudrā), images, rosaries, manḍalas, offerings, etc." into a single category she calls "special conditions" (McDermott 1975, p. 286). "Special conditions" is distinguished in her schema from "normal conditions" by which she means those having specifically to do with the requirements for communicative language, such as both speaker and hearer sharing the same language. Because the category of normal conditions is so tied to instrumental conceptions of language use, what she calls "any serious kind of language use" (McDermott 1975, p. 286), we disregard that category in developing the idea of ritual pragmatics here. Such special conditions are prescribed by the tradition and are understood as part of the criteria for successful ritual performance. Next, she describes the person reciting the mantra in terms of the qualifications needed to recite with efficacy, referred to as "charisma." The reciter needs to be ritually purified, morally proper, possess the necessary practical skills and education, and be properly initiated into the cult (McDermott 1975, p. 286). This list of characteristics privileges a doctrinal view from the perspective of an institution, sect, or lineage. The emphasis on authoritative certification is even clearer in McDermott's assertion that "the sine qua non of the efficacy of any mantra is 'permission of speech'", that is, an authoritative transmission from preceptor to disciple (McDermott 1975, pp. 286-87).

Next, she identifies aspects of what she calls the correct and complete execution of the recitation procedure. This includes four items: Propositional content of the mantra, predication of the practitioner as empowered, prior recitations, and recitation without flaw or infelicity. Except for the idea that mantra have propositional content, which places mantra in the category of communicative use of language, the standards involved in these aspects again appear to be based on doctrinal concepts.

Lastly, McDermott considers the issue of the sincerity of the execution. For this, it is necessary that the practitioner, auditor, and practitioner's preceptor believe that the metaphysical system is true, that the practitioner actually intends the outcome, that the recitation empowers the practitioner, and that the mantra will be effectuated by being uttered. She adds that the practitioner also intends to produce the belief in the auditor that the mantra is effective by its being the one conventionally employed to attain the goal of recitation. Notions of sincerity are part of linguistic pragmatics because they are key to successful communication.

McDermott's use of the idea of pragmatics adheres closely to a strong analogy between mantra recitation and linguistic activity. This is evident in that the discussion is framed by J.L. Austin and John Searle, but also by the role of Richard Montague's ideas regarding the analysis of pragmatics as "employing an index or point of reference, $i$, which consists of an $n$-tuple comprising the complex of the $n$ relevant aspects of a given context of use" 
(McDermott 1975, n. 16). As noted above, her understanding of relevance often references doctrinal concerns noted by Beyer.

Research since the time of McDermott's essay indicates that the analogy between ritual and language needs to be looser. The way that language is conceptualized is as conveying meaning, hence McDermott's attention, for example, to the propositional meaning of mantra. The philosophical background focuses even more closely on the conditions for the truth of a proposition. This is where the strong analogy behind McDermott's pragmatics becomes problematic. Ritual is activity, and activity may be intended and interpreted as having meaning, but is not itself meaningful, and is therefore in itself neither true nor false. The way in which we borrow technologies from linguistics needs to be adaptive, rather than uncritical. Naphtali S. Meshel's study of ancient Israelite sacrificial rituals, for example, demonstrates that the grammar of that ritual system does not "resemble the morphology or syntax of natural languages" (Meshel 2014, p. 27). Thus, rather than imposing a pragmatics based on language onto ritual, the pragmatics needs to be drawn out of ritual. In the next section, after introducing the ritual system of Yoshida Shintō, a comparison between the Yoshida Shintō goma and the Shingon goma will establish some of the relevant pragmatic factors empirically rather than a priori.

\section{Building a Hybrid Ritual}

Kanetomo established a complex ritual system (Scheid 2001, pp. 157-61). Of the many rituals established by Kanetomo the three most important are: dials),

[Sangen] Jūhachi shintō: The eighteen divine ways [or, actions] (of the three primor-

Sōgen gyōbō: Ceremony of the primordials [a "Northern Dipper" (Big Dipper, Ursa Major) ritual],

Yoshida shintō daigoma: Great fire ritual of the Yoshida shintō (Scheid 2001, p. 171).

The “Eighteen divine acts" (Jühachi shintōo, 十八神道), the first of the three Yoshida rituals formulated by Kanetomo, is a very close rewriting of the Shingon Jūhachidō (眞言十 八道). This latter is the first of the four rituals constituting the training of a Shingon priest (Payne 2011c). The structure of the two rituals is fundamentally the same. A comparative analysis of these two rituals supports the thesis that ritual structure is the slowest ritual element to change as rituals are transmitted from one ritual culture to another, or as in this case, adapted in such a fashion as to create a ritual for a new religious tradition (Payne 2011a).

The "Ceremony of the Primordials" (Sōgen gyōbō, 宗源行法) is a ritual devoted to the Northern Dipper (Ch. beidou, 北斗), demonstrating the adoption of content for the Yoshida rituals from Daoist sources, whether proximately or remotely (Mollier 2008, pp. 134-73; also, Masuo 2000, pp. 826, 27). That is, it might have been appropriated directly from Daoist sources, or been borrowed from a Shingon Northern Dipper ritual.

\subsection{Yoshida Goma}

The homa (Jpn. goma, 護摩) ritual performed in the Yoshida tradition had at least four different versions (Demura 1997, pp. 374-428; also, Shintō Taikei Hensankai 1978-1993, Ronsetsu hen 9: 19-45). The Yoshida Shintō goma manuals under examination here are held in the rare book collection of the Tenri Central Library (Tenri City, Japan), as part of an extensive collection of premodern Shintō materials. Identifying these by their accession numbers:

Accession number 653722, title page gives the ritual name as "Yuiitsu Shintō goma ryaku shidai" ("abridged manual for the Yuiitsu Shintō goma", 唯一神道護摩略次第), cover: "Shō goma shidai" ("short goma manual", 小護摩次第),

Accession number 653911, title page gives the ritual name as "Yuiitsu Shintō dai goma ryaku shidai" ("abridged manual for the great Yuiitsu Shintō goma", 唯一神道略次第), cover: “Goma shidai" ("manual for the goma”, 護摩次第), 
Accession number 653618, title page gives the ritual name as "Yui Shintō dai goma shidai" ("manual for the great Yui Shintō goma", 唯神道大護摩次第), cover: “Yuiitsu Shintō dai goma hō" ("procedure for the great Yuiitsu Shintō goma", 唯一神道大護摩). Note that the last character of the cover title, hō 法, is the translation for Skt. dharma, and is rendered here as "procedure", which is its meaning in East Asian Buddhist ritual culture as well.

Accession number 653551, title page gives the ritual name as "Yui Shintō dai goma shidai" ("abridged manual for the great Yuiitsu Shintō goma", 唯神道大護摩次第). (Cover title not recorded).

\subsection{A Pragmatic Analysis}

A key part of the context of the Yoshida goma is the Shingon tradition and its goma. The following analysis attempts to move beyond simply comparing and contrasting to exploring what pragmatic elements, which in keeping with McDermott's terminology we call indices, were important to Kanetomo and later practitioners as distinguishing a Yoshida Shintō goma from a Shingon one. By contrast, the indices that are not distinguished then in turn suggest continuity of ritual practice across this sectarian divide. This is an attempt to allow the pragmatic indices that were significant to the practitioners of the ritual to emerge from the comparison, rather than presuming that the pragmatic indices relevant to spoken communications are equally applicable to ritual.

\section{(1) Basic Structure}

The Yoshida Shintō goma includes mantras and other offerings made to Yoshida Shintō deities in much the same fashion that offerings are made to buddhas and bodhisattvas in a Shingon goma. At the level of ritual structure, the overall pattern of actions appears to be largely the same. The practitioner approaches the altar, engages in purifications, and then proceeds with igniting a fire and making offerings into it. This pattern seems consistent at least from medieval tantric Indian practices and employs the even older ritual metaphor of hosting an honored guest. Bernhard Scheid suggests that the effects of the three cultural levels (Indian, Chinese, and Japanese) can be understood on the analogy with linguistics - that there is a Japanese Shintō phonology, a Chinese Daoist morphology, and an Indian Buddhist syntax (Scheid 2001, p. 184). In broad terms, this analogy is helpful, apparently intended as suggestive rather than literal.

\section{(2) Practitioner}

Instead of an "objective" checklist of criteria that qualify the reciter of mantra as in McDermott, the context and use approach being suggested here treats the ritual practitioner situationally. In other words, what religio-social role is the practitioner performing in the ritual? The Yoshida Shintō tradition is now no longer extant, so it is an assumption that the practitioner is acting either explicitly as a Shintō priest for the Yoshida goma or explicitly as a Buddhist priest for the Shingon goma. That assumption is supported, however, by the initiatory nature of both traditions-a practitioner would consequently probably only consider themselves qualified to perform such a ritual if they were initiated into the tradition. Despite a superficial similarity, the religio-social role of the practitioner is distinct from concern with the qualifications of the practitioner focused on by McDermott. This question of the religio-social role is not simply hypothetical, as there are instances today of Tendai priests engaging in the performance of rituals that originated as Shintō ceremonials. Which role they are fulfilling constitutes a key pragmatic index of the ritual.

(3) Altar, Hearth, Implements, and Offerings

One of the differences between the Yoshida goma and the Shingon is the shape of the altar and hearth upon which the fire is built. The Shingon altar is four sided, with the hearth in the middle, a pattern also found in other Shingon altars where a pagoda is in the center of the altar rather than a hearth (cf. Toganoo 1982, figures on 235, 236, 237, 238). The overall symbolism is that of a mandala. A further layer of symbolism 
lies in the correlations between pagodas as representations of the five (or sometimes six) elements that constitute the existence of buddhas, humans, and the cosmos itself, making all three-pagoda, buddha, and practitioner - symbolically coterminous. Thus, the pagoda at the center of a mandala altar makes manifest the presence of a buddha, and in the same way the fire in the hearth on a goma altar also makes manifest the presence of the buddhas, bodhisattvas, protective deities, and celestial and worldly deities evoked in the course of the ritual. At the same time, the practitioner is also identified with both the fire and the deities evoked in the hearth. In the Shingon tradition, the shape of the hearth on the altar is prescribed as varying depending on the purpose of the goma being performed. In contrast, the Yoshida goma altar on display in the Kokugakuin museum (Figures 1 and 2) employs a circular hearth (Grapard provides an illustration of a Yoshida Shintō altar, though not specifically a goma altar, and of Yoshida Shintō ritual implements; Grapard 1992, figures on 49 and 51).

As a mandala, the Shingon altar is square, while the Yoshida altar is eight-sided (Figures 1 and 2). Like octagonal patterns frequently encountered in Daoist, neo-Confucian, and popular Chinese religion, the Yoshida Shrine, Taigenkyū, itself is also eight-sided (Figure 3, see also (Grapard 1992), figures on 54, 55, and 57), and matches the shape of the Yoshida altar (Figures 1 and 2). Other than these different shapes, however, the altar appointments are similar to those of the Shingon version. The arrangement includes ladles for making offerings, wands for purification, and two side tables. Within the Shingon tradition, details regarding the location of ritual implements and offerings are found in a range of variations (Toganoo 1982, p. 249). While not specifically matching, the arrangement of the Yoshida Shintō goma altar may expand the range of variation but remains similar enough to be considered simply a variant.

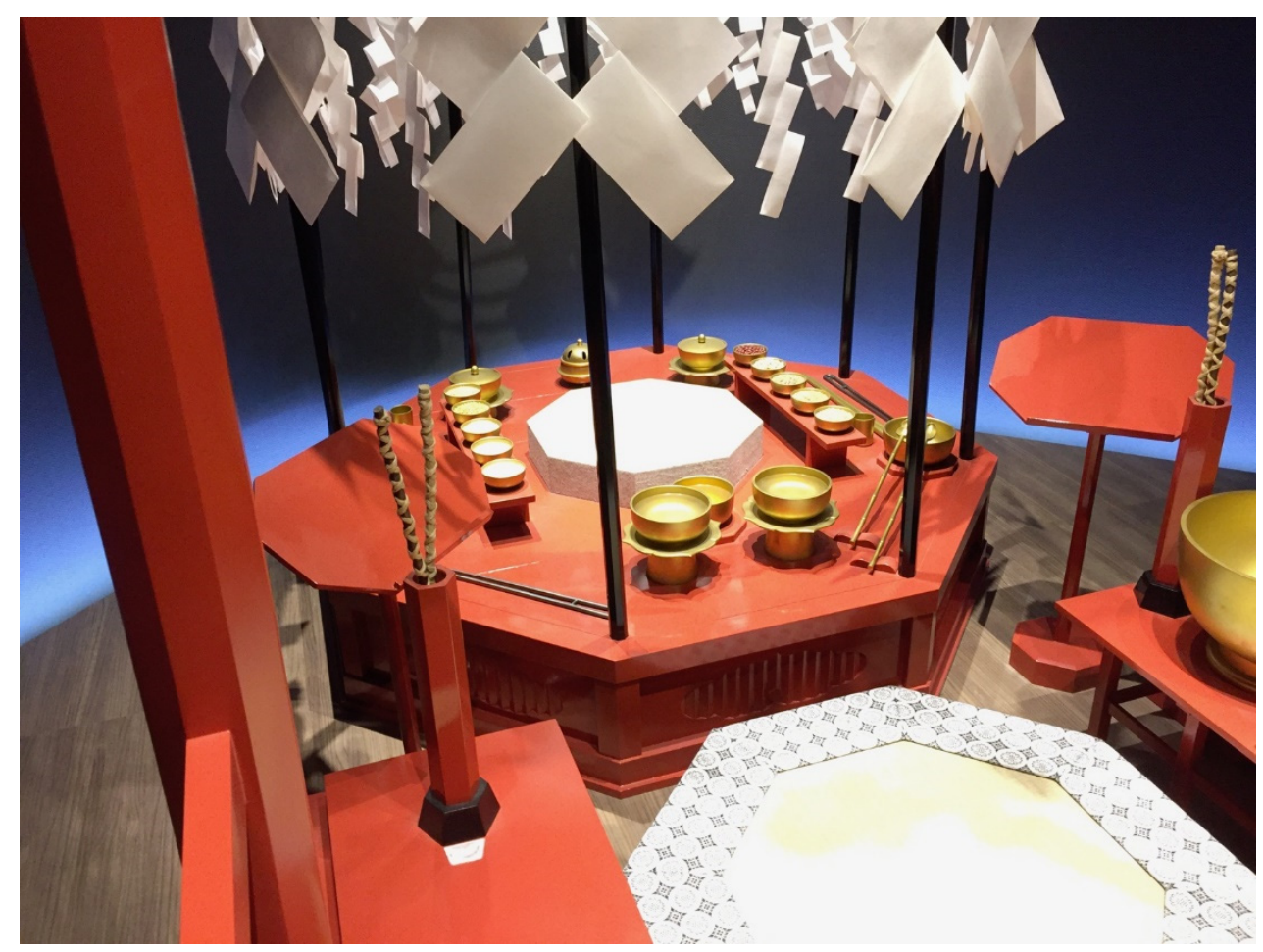

Figure 1. Yoshida Shintō goma altar in the Kokugakuin Museum, Tokyo (photo Payne, with permission: Kokugakuin Museum). 


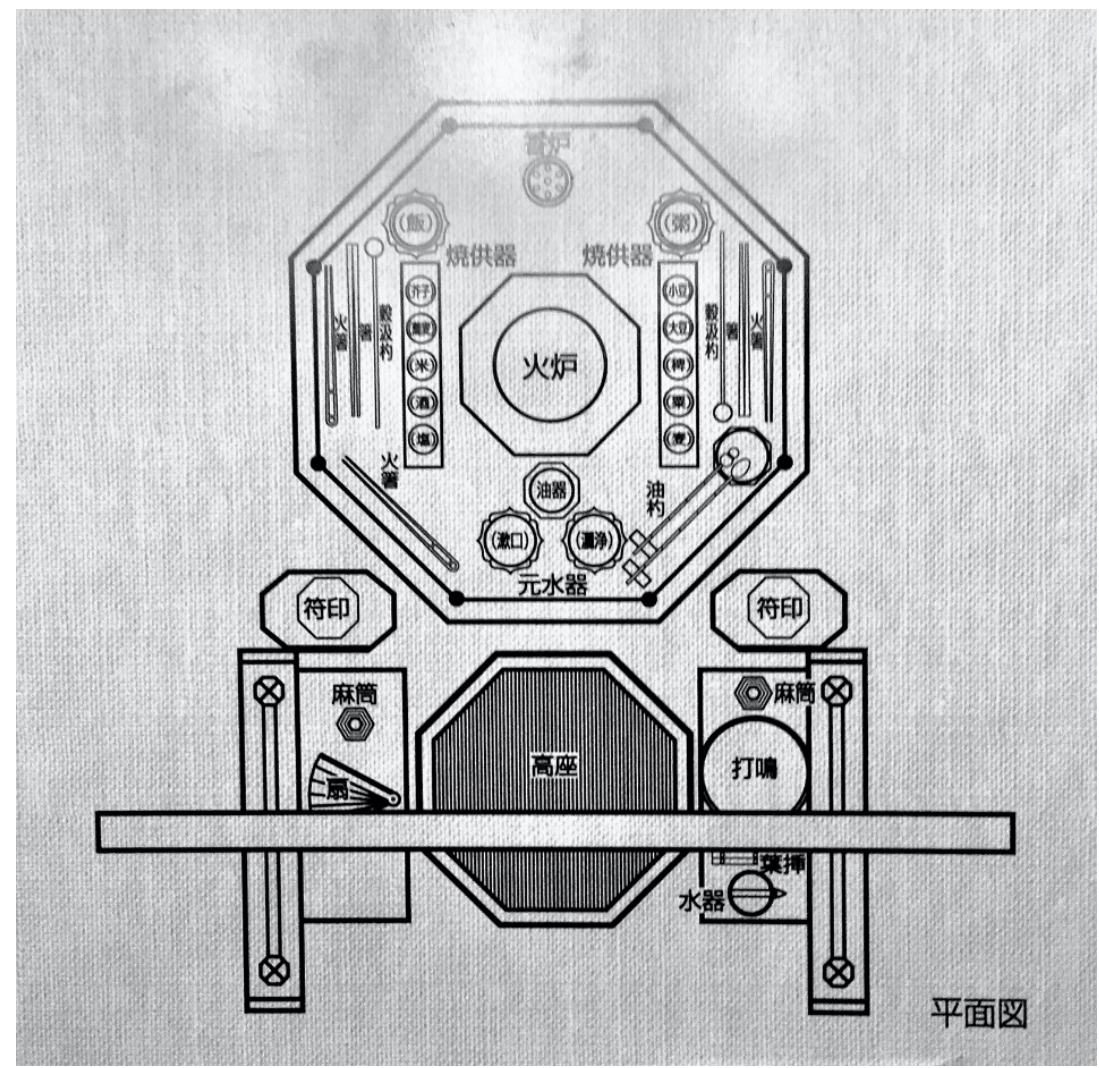

Figure 2. Diagram of Yoshida Shintō goma altar from explanatory plaque for altar in Figure 1 (photo Payne, with permission: Kokugakuin Museum).
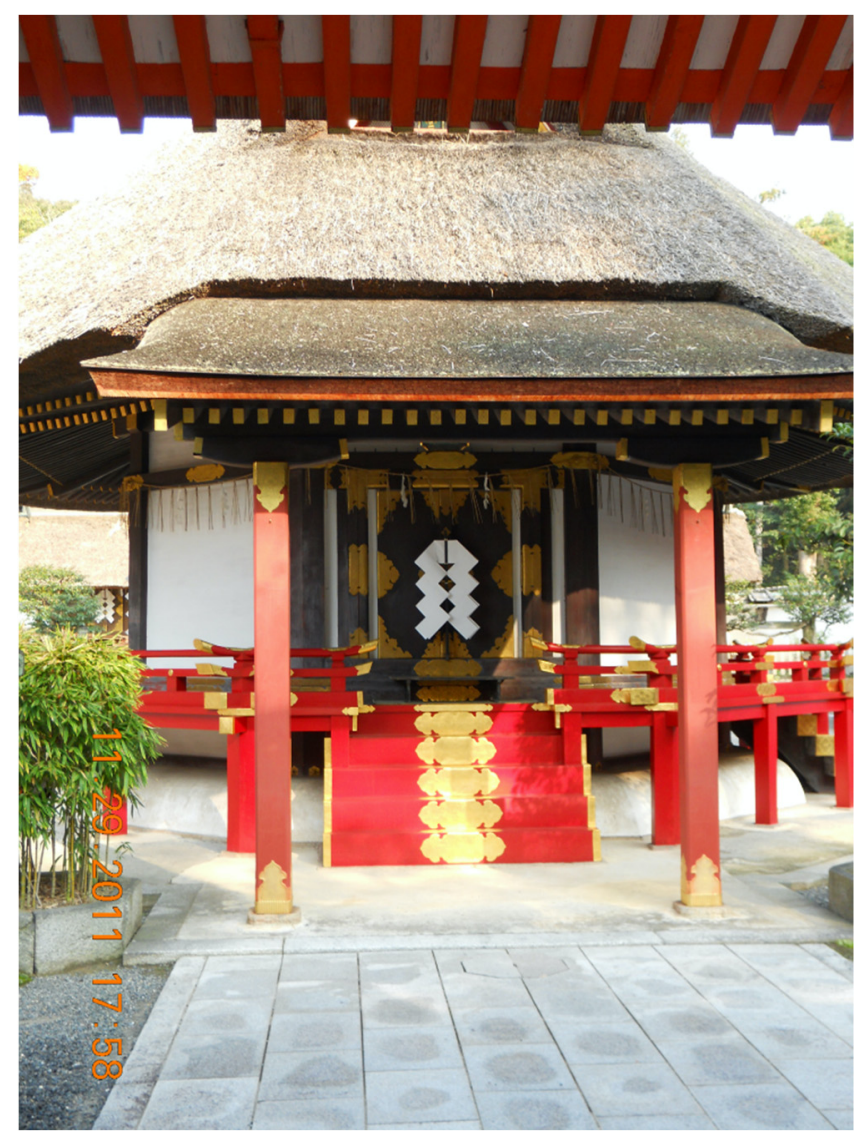

Figure 3. Yoshida Shrine, Taigenkyū, Kyoto (photo Payne). 


\section{(4) Recitations and Mudrās}

Unlike many Shingon ritual manuals and goma ritual manuals from other Shintō traditions that I have examined, the Yoshida manuals examined here do not employ mantras of Sanskrit origin or modelled on Sanskrit mantras; nor is there any use of Siddham script, a Sanskrit script predating the Devanagari script most familiar today, which is widely used in Japanese Buddhism, particularly for ritual purposes both historically and into the present. Scheid describes the recitation formula used as being "mantra-like" and as in some cases taking the form of a short waka (和歌) poem (Scheid 2001, pp. 176, 78). In the manuals, these are referred to not as mantra (shingon 眞言), but rather as "empowerments" (kaji 加持, Skt. adhișthāna) (see Tinsley 2011, p. 705; Drummond 2011, p. 822).

In Shingon ritual practice, and much of tantric practice more widely, mantra and mudrā are understood as part of the same ritual action. Again, unlike many Shingon ritual manuals and goma ritual manuals from other Shintō traditions, the Yoshida manual examined here does not include illustrations of mudrā. However, Scheid notes just such a connection between recitation and mudrā, and provides illustrations of three mudrā (Scheid 2001, pp. 176, 77). The first of these is called the "mudrā of the eight directions" (八府印), which is the same as the Shingon mudrā called the "mudrā of the eight petals" (八葉の印, mudrā number 55 in Mikkyō Jiten Hensankai [1969] 1983, appendices, 42). The second is the "mudrā of the three lights" (三光印), which is the same as "mudra of Kannon's unfailing rope snare", (不空羅索観音の印, mudra number 52, similar also to numbers 41, and 48 in Mikkyō Jiten Hensankai [1969] 1983, appendices, 42). The third is the "mudrā of the sun wheels" (日輪印), which, however, does not match any of the mudrās in the catalogue of Shingon mudrās found in the Mikkyō daijiten (Mikkyō Jiten Hensankai [1969] 1983, appendices, pp. 39-65).

\section{(5) Variations? or Anomalies?}

Examination of these manuals reveals some discrepancies. Given the limited nature of the corpus, however, these can only be noted as either possible variations or anomalies. The two that stand out are the way in which the kindling is arranged, and the shape of the altar.

Regarding the arrangement of kindling, two manuals include illustrations of the way that the kindling is to be stacked on the hearth. Manual 653551 includes an illustration that shows a triangular arrangement (Figure 4), while manual 653722 shows a square arrangement (Figure 5). This detail may be simply a variation within the tradition or point to different tantric Buddhist models for the ritual: While Shingon always uses square arrangements of the sticks of kindling, Tendai gomas use a triangular arrangement in the course of the ritual sequence.

Concerning the shape of the altar, manual 653551 includes two illustrations of a Yoshida Shintō altar, one of which (Figure 6) is ambiguously six- or eight-sided, and the second (Figure 7) is definitely six-sided. The eight-sided Yoshida Shintō altar shown in Figures 1 and 2 may be taken as normative, leaving the six-sided version, which is also found in another esoteric Shintō goma manual, unexplained.

Some aspects of the context and use of the Yoshida Shintō goma can be considered pragmatic indices, that is, as conveying significance. The motivating question here has been how Yoshida Shintō and Shingon gomas were distinguished. In answer, we consider which indices differ between the Yoshida goma and the Shingon goma, as well as goma being performed by other traditions in premodern Japan. First, the ritual employs the same metaphor, that of host-guest feasting, which structures not only many tantric rituals but plays an important role in Vedic ritual practices as well. This further confirms the theory that ritual structure, i.e., syntax, is the aspect of ritual to change most slowly. It also highlights the important role of ritual metaphors. Feasting an honored guest was itself a cultural practice in Japan, and therefore the ritual metaphor originating in Vedic culture could easily be adopted. The index of the basic structure shows continuity between the 
Yoshida Shintō goma and the gomas of Shingon and other esoteric Buddhist traditions in the premodern period.

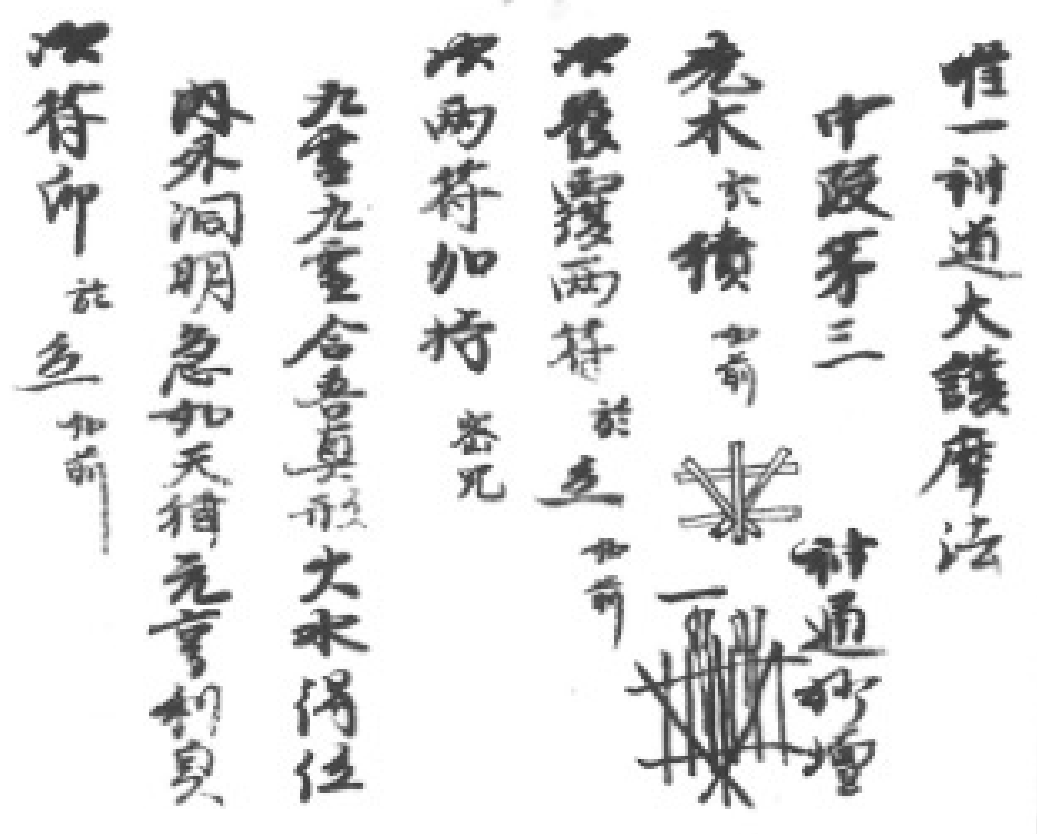

Figure 4. Triangular arrangement of kindling (manual 653551).

The ritual identity of the goma practitioner, however, would mark a contrast. Such rituals would be performed by initiates into either the Yoshida or, conversely, Shingon traditions. This is not to say that individual practitioners might not be initiated into both, but even in that case, they would have performed the Yoshida Shinto goma as a Yoshida initiate.

The next set of suggested indices-altar, hearth, implements, and offerings-show both continuity and distinction. The Yoshida altar is eight-sided, reflecting an ideological orientation to Chinese cosmology, that is, one shared by both Daoist and neo-Confucian traditions. The Yi Jing had, for example, become an increasingly popular topic of study both by members of the court and Buddhist monastics from the thirteenth century, two centuries before Kanetomo (Ng 1997, p. 26). This is a marked distinction from esoteric Buddhist altars that are homologized with mandala, and altar shape is therefore an important pragmatic index. It is also noteworthy that the Yoshida practitioner sits under an archway (Figures 1 and 2, cf. Grapard 1992, p. 49) that appears similar to torii archways marking the entry to a Shintō shrine. This does not have a direct correlate in the arrangement of Shingon altars, and therefore strengthens the altar as marking distinction.

The hearth shape, implements, and offerings, however, apparently do not mark distinction nearly so strongly. Although the tantric Buddhist tradition does allow for a variety of hearth shapes, functionally the circular shape is the one almost universally employed in temples in Japan and is not a distinguishing index. The implements appear to be more similar than might be expected based only on the constraints of practical concerns in the ritual performance, such as making offerings into the fire. Specifically, for example, the two ladles on the right in Figures 1 and 2 show the same shape as the two 
used for offering oil in a Shingon goma. Offerings made are also quite similar. Again, this suggests that the form of the ritual itself endured across adoption into the Yoshida tradition, while the setting was adapted, perhaps because it is more strongly visible as a marker of distinction.

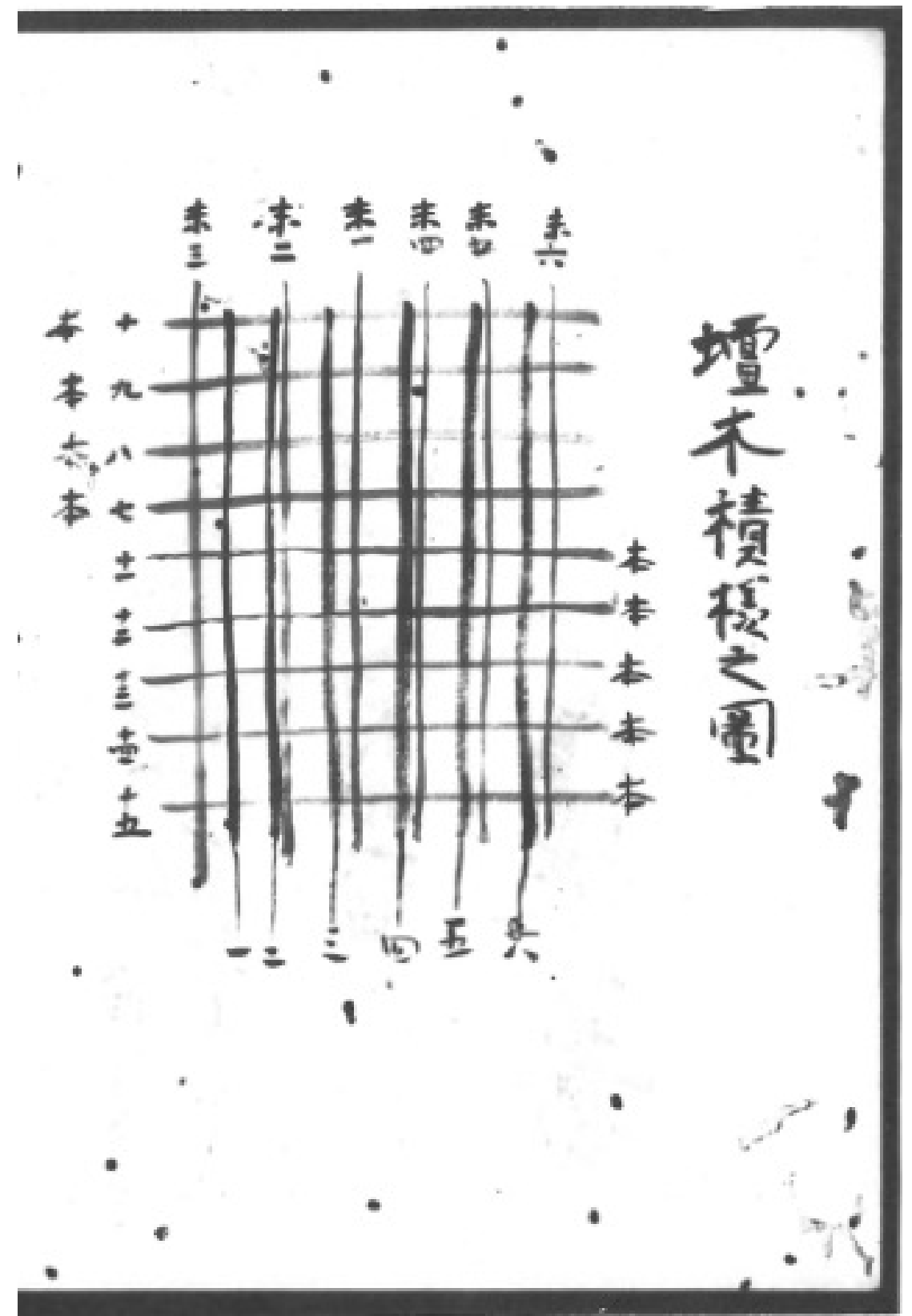

Figure 5. Square arrangement of kindling (manual 653722). 


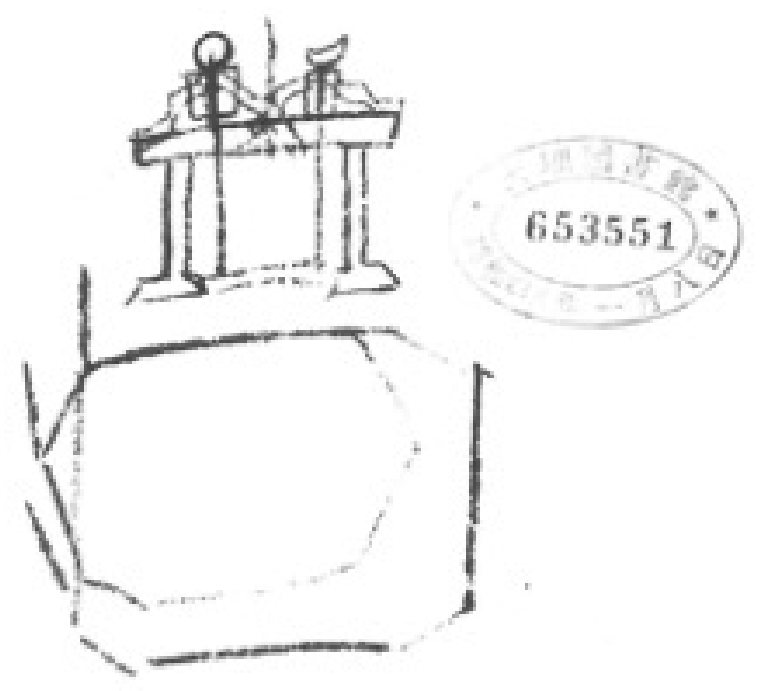

Figure 6. Yoshida Shintō altar illustration from manual 653551, showing torii archway with sun and moon.

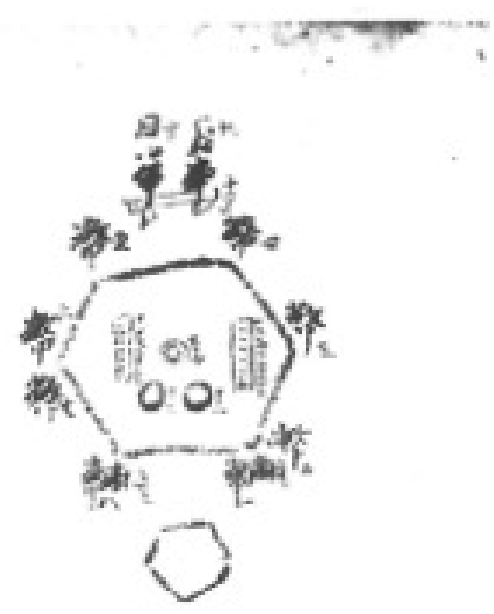

Figure 7. Six-sided altar (manual 653551).

Both traditions link recitation and mudrā in the ritual performance, which is rooted in Indic tantric conceptions that neither recitation nor mudrā alone are ritually effective but must be performed together. What is recited, however, does serve as an index of distinction. Shingon, Tendai, and some of the other Shintō traditions employed mantra deriving from Sanskrit, even to the extent of using Siddham script in their ritual manuals. The Yoshida, by contrast, created recitations in waka form. Thus, within the shared conceptions of ritual efficacy, and employing mudrā often indistinguishable from Buddhist ones, Yoshida 
focused on distinguishing their recitations-again, perhaps because, like the ritual setting, these would have been more evident to observers than the accompanying mudrā.

The claim being made here is not that this set of eight pragmatic indices (basic structure, ritual identity of the practitioner, altar, hearth, implements, offerings, recitations, and mudrā) is either a comprehensive or a definitive set of pragmatic indices for the consideration of the Yoshida Shintō ritual tradition, much less for ritual in general. Following on McDermott's essay, this is a second step toward a pragmatics of ritual. It does, however, suggest which indices were and were not important to Kanetomo and later practitioners for claiming that the Yoshida Shintō goma was distinct from the Shingon goma. Further, the analysis is based on the factors revealed by an examination of the ritual as prescribed in manuals employed by actual practitioners, rather than imposed from a methodological presupposition that privileges linguistic categories over the practices of a ritual culture.

\section{Conclusions}

The hybrid character of Yoshida Shintō is well recognized. This essay has explored the utility of "use and context" as an analytic approach, that is, a pragmatics of ritual. Drawing on McDermott's preliminary essay, the approach employed there was critiqued as depending on a misleading equivalence of spoken communication and ritual. Employing a "softer" conception of pragmatics, framed as context and use, allows for the relevant pragmatic elements to emerge from ritual practices, rather than being imposed on the data a priori. This revised form of pragmatics is more responsive to ritual per se and provides a heuristically productive means by which to understand how rituals so similar to one another are identified by their practitioners either as Shingon Buddhist or Yoshida Shintō gomas. As a definitional strategy, a pragmatics of ritual avoids the pseudoproblems created by pre-existing ideas of traditions as monolithic and mutually exclusive. Context and use allow for clearer analysis of interactions, influences, and borrowings as dynamic processes happening between traditions, rather than value-laden judgements such as syncretism and unorthodoxy.

Funding: This research received no external funding.

Institutional Review Board Statement: Not applicable.

Informed Consent Statement: Not applicable.

Data Availability Statement: Not applicable.

Acknowledgments: I would like to express my deep appreciation to Ikuo Higashibaba for his invaluable assistance in helping me to access the rare book collection of the Tenri Central Library (Tenri City, Japan). I am also deeply appreciative of the assistance of my friends in Tokyo for their assistance with visiting the Kokugakuin Museum and obtaining permissions from the Kokugakuin Museum. My thanks also to the staff of the Kokugakuin Museum for allowing me to photograph the display of the goma altar, and for permission to publish photographs number 1 and 2 included here. I am also grateful to the three anonymous reviewers, who provided valuable feedback that improved this work significantly.

Conflicts of Interest: The author declares no conflict of interest.

\section{Notes}

1 The category of diviners ("urabe") are known from very early in Japanese history (Kidder 2007, p. 127). Some scholars have questioned whether it is appropriate to treat all "diviners" in early Japan as members of a single clan (uji, 氏, fictive family group), that is, the Urabe. Allan Grapard has argued in response that "those 'urabe' who were active in Nara and Kyoto are, in my view, related and treated as such in the Kojiki [712] and Nihon shoki [720] narratives mentioning their ancestral kami" (Grapard 2002, p. 223, n. 9). Though the term may have also been used for diviners more generally, as Grapard argues the identification of an ancestral kami indicates that the Urabe were considered a clan at this time. (See also Kory 2015, p. 352). For a full discussion of the Urabe origins, (see Grapard 1992, pp. 30-31).

2 Bernhard Scheid gives the date 987 for this event, citing "Yoshida lore" and the diary of Fujiwara Sanesuke (Scheid 2001, p. 78). 


\section{References}

Andreeva, Anna. 2010. The Karmic Origins of the Great Bright Miwa Deity: A Transformation of the Sacred Mountain in Premodern Japan. Monumenta Nipponica 65: 245-96. [CrossRef]

Andreeva, Anna. 2017. Assembling Shinto: Buddhist Approaches to Kami Worship in Medieval Japan. Cambridge and London: Harvard University Press.

Beyer, Stephen. 1973. The Cult of Tārā: Magic and Ritual in Tibet. Berkeley, Los Angeles and London: University of California Press.

Bouchy, Anne. 2009. Transformation, Rupture, and Continuity: Issues and Options in Contemporary Shugendō. Cahiers d'ExtrêmeOrient 18: 17-45. [CrossRef]

Bowring, Richard. 2005. The Religious Traditions of Japan: 500-1600. Cambridge: Cambridge University Press.

Breen, John, and Mark Teeuwen. 2010. A New History of Shintō. Chichester: John Wiley \& Sons.

Brown, Robert L. 2002. Introduction. In The Roots of Tantra. Edited by Katherine Anne Harper and Robert L. Brown. Albany: State University of New York Press, pp. 1-14.

Demura, Katsuaki. 1997. Yoshida Shintō no Kisoteki Kenkyū. Kyoto: Shintō Shigakkai.

Drummond, Donald. 2011. Looking Back and Leaping Forward: Constructing Lineage in the Shingi-Shingo Tradition of Japan. In Esoteric Buddhism and the Tantras in East Asia. Edited by Charles D. Orzech, Henrik H. Sørensen and Richard K. Payne. Leiden and Boston: Brill, pp. 815-26.

Grapard, Allan G. 1992. The Shinto of Yoshida Kanetomo. Monumenta Nipponica 47: 27-58. [CrossRef]

Grapard, Allan G. 2002. Shrines Registered in Ancient Japanese Law: Shinto or Not? Japanese Journal of Religious Studies 29: 209-32. [CrossRef]

Grapard, Allan G. 2006-2007. Medieval Shintō Boundaries: Real or Imagined? Cahiers d'Extrême-Asie 16: 1-18. [CrossRef]

Hardacre, Helen. 2017. Shinto: A History. Oxford and New York: Oxford University Press.

Hodge, Stephen, trans. 2003. The Mahāvairocana Abhisaṃbodhi Tantra, with Buddhaguhya's Commentary. London and New York: Routledge Curzon.

Janssen, Theo M. V., and Thomas Ede Zimmermann. 2021. Montague Semantics. In The Stanford Encyclopedia of Philosophy. Edited by Edward N. Zalta. Stanford: Metaphysics Research Lab, Philosophy Department. Available online: https://plato.stanford.edu/ archives/sum2021/entries/montague-semantics/ (accessed on 12 June 2021).

Kidder, J. Edward, Jr. 2007. Himiko and the Elusive Chiefdom of Yamatai: Archaeology, History, and Mythology. Honolulu: University of Hawai'i Press.

Kory, Stephan N. 2015. From Deer Bones to Turtle Shells: The State Ritualization of Pyro-Plastromancy during the Nara-Heian Transition. Japanese Journal of Religious Studies 42: 339-80. [CrossRef]

Kuroda, Toshio. 1996. The Development of the Kenmitsu System as Japan's Medieval Orthodoxy. Translated by James C. Dobbins. Japanese Journal of Religious Studies 23: 233-69. [CrossRef]

Maeda, Hiromi. 2002. Court Rank for Village Shrines: The Yoshida House's Interactions with Local Shrines during the mid-Tokugawa Period. Japanese Journal of Religious Studies 29: 325-58. [CrossRef]

Maeda, Hiromi. 2003. Imperial Authority and Local Shrines: The Yoshida House and the Creation of a Countrywide Shinto Institution in Early Modern Japan. Ph.D. dissertation, Harvard University, Cambridge, MA, USA.

Masuo, Shin'ichirō. 2000. Daoism in Japan. In Daoism Handbook. Edited by Livia Kohn. Leiden, Boston and Köln: Brill, pp. 821-42.

McDermott, A. C. Senape. 1975. Towards a Pragmatics of Mantra Recitation. Journal of Indian Philosophy 3: 283-98. [CrossRef]

Meshel, Naphtali S. 2014. The Grammar of Sacrifice: A Generativist Study of the Israelite Sacrificial System in the Priestly Writings. Oxford and New York: Oxford University Press.

Mikkyō Jiten Hensankai. 1983. Mikkyō dai Jiten. Kyoto: Hōzōkan. First published 1969.

Miyake, Hitoshi. 1989. Religious Rituals in Shugendo: A Summary. Japanese Journal of Religious Studies 16: 101-16. [CrossRef]

Miyake, Hitoshi. 2001. Shugendō: Essays on the Structure of Japanese Folk Religion. Ann Arbor: Center for Japanese Studies, University of Michigan.

Mollier, Christine. 2008. Buddhism and Taoism Face to Face: Scripture, Ritual, and Iconographic Exchange in Medieval China. Honolulu: University of Hawai'i Press.

$\mathrm{Ng}$, Wai-ming. 1997. The History of the 'I Ching' in Medieval Japan. Journal of Asian History 31: 25-46.

Nickel, Lukas. 2011. The Prehistory of Religion in China. In The Oxford Handbook of the Archaeology of Ritual and Religion. Edited by Timothy Insoll. New York and Oxford: Oxford University Press, pp. 442-54. [CrossRef]

Orzech, Charles D. 1989. Seeing Chen-Yen Buddhism: Traditional Scholarship and the Vajrayāna in China. History of Religons 29: 87-114. [CrossRef]

Orzech, Charles D. 2006. The 'Great Teaching of Yoga', the Chinese Appropriation of the Tantras, and the Question of Esoteric Buddhism. Journal of Chinese Religions 34: 29-78. [CrossRef]

Orzech, Charles D., Henrik H. Sørensen, and Richard K. Payne, eds. 2011. Esoteric Buddhism and the Tantras in East Asia. Leiden and Boston: Brill.

Payne, Richard K. 2011a. Conversions of Tantric Buddhist Ritual: The Yoshida Shintō Jūhachishintō ritual. In Transformations and Transfer of Tantra in Asia and Beyond. Edited by István Keul. Berlin: Walter de Gruyter, pp. 365-98.

Payne, Richard K. 2011b. Ritual Studies in the Longue Durée: Comparing Shingon and Śaiva Siddhānta Homas. Pacific World: Journal of the Institute of Buddhist Studies 13: 223-62. 
Payne, Richard K. 2011c. The Fourfold Training in Japanese Esoteric Buddhism. In Esoteric Buddhism and the Tantras in East Asia. Edited by Charles D. Orzech, Henrik H. Sørensen and Richard K. Payne. Leiden and Boston: Brill, pp. 1024-28.

Payne, Richard K. 2018. Language in the Buddhist Tantra of Japan: Indic Roots of Mantra. London and New York: Bloomsbury Academic.

Payne, Richard K. 2021. Conscious and Unconscious Dynamics in the Secularizing Discourse. In Secularizing Buddhism: New Perspectives on a Dynamic Tradition. Edited by Richard K. Payne. Boulder: Shambhala Publications, pp. 285-314.

Scheid, Bernhard. 2001. Der Eine und Einzige Weg der Götter: Yoshida Kanetomo und die Erfindung des Shinto. Vienna: Verlag der Österreichischen Akademie der Wissenschaften.

Scheid, Bernhard. 2006. Two modes of secrecy in the Nihon shoki transmission. In The Culture of Secrecy in Japanese Religion. Edited by Bernhard Scheid and Mark Teeuwen. Abingdon and New York: Routledge, pp. 284-306.

Scheid, Bernhard, and Mark Teeuwen, eds. 2006. The Culture of Secrecy in Japanese Religion. Abingdon and New York: Routledge.

Schopen, Gregory. 1982. The Text on the 'Dhāran̄ī Stones from Abhayagiriya': A Minor Contribution to the Study of Mahāyāna Literature in Ceylon. Journal of the International Association of Buddhist Studies 5: 100-8.

Sekimori, Gaynor. 2011. Shugendō and Its Relationship with the Japanese Esoteric Sects: A Study of the Ritual Calendar of an Edo-Period Shugendō Shrine-Temple Complex. In Esoteric Buddhism and the Tantras in East Asia. Edited by Charles D. Orzech, Henrik H. Sørensen and Richard K. Payne. Leiden and Boston: Brill, pp. 997-1008.

Shintō Taikei Hensankai. 1978-1993. Shintō Taikei. 28 vols. Tokyo: Shintō Taikei Hensankai.

Strickmann, Michel. 1983. Homa in East Asia. In Agni: The Vedic Ritual of the Fire Altar. Edited by Frits Staal. Berkeley: Asian Humanities Press, vol. II, pp. 418-55.

Teeuwen, Mark. 2002. From Jindō to Shinto: A Concept Takes Shape. Japanese Journal of Religious Studies 29: 233-63. [CrossRef]

Tinsley, Elizabeth. 2011. Kūkai and the Development of Shingon Buddhism. In Esoteric Buddhism and the Tantras in East Asia. Edited by Charles D. Orzech, Henrik H. Sørensen and Richard K. Payne. Leiden and Boston: Brill, pp. 691-708.

Toganoo, Shoun. 1982. Himitsu jisō no kenkyū. Kōyasan: Kōyasan Daigaku Mikkyō Bunka Kenkyūjo, Kyoto: Sōhatsubaimoto Rinsen Shoten.

Urban, Hugh. 2003. Tantra: Sex, Secrecy, Politics, and Power in the Study of Religion. Berkeley, Los Angeles and London: University of California Press. 